\title{
Status gizi, aktivitas fisik, dan prestasi akademik siswa SMA gakin dan non-gakin di Kota Bitung
}

\author{
Daniel Robert ${ }^{1}$, Abidillah Mursyid $^{2}$, Emy Huriyati ${ }^{3}$
}

\begin{abstract}
Background: A good nutritional status of students will greatly support their physical activities. Social economic status of a family may affect intake of nutrient, energy, and protein which can bring impact on nutritional status. Good nutritional status is necessary for teenagers to maintain health and support physical activities. Senior high school students from poor and non poor families may have different nutritional status, physical activities, and academic achievement.

Objectives: The objectives of the study were to identify differences in nutritional status, physical activities, and academic achievement of students from poor and non poor families at Bitung Municipality and relationship between intake of energy and protein and nutritional status, physical activities, and academic achievement of students from poor and non poor families.
\end{abstract}

Methods: The study was observational with cross sectional design. Population and samples were senior high school students of 16-18 years old (from database) from poor and non poor families. Total samples were 314 students taken using stratified random sampling technique. The study was conducted in September-December 2005. Data were analyzed using chi-square, $t$-test, and linear regression with significance level $95 \%$ and processed using computer software. Results: There was a significant difference in nutritional status, light physical activity, academic achievement in poor and non poor highschool students $(p<0,05)$, but there was no significant difference in the medium and heavy physical activity $(p>0,05)$. There was also a relationship between confounding variable of energy intake with nutritional status, father's job with light activity, father's education and job with medium activity, father and mother's education, father's job, and energy intake with academic achievement. There was no relationship between confounding variable with heavy physical activity $(p>0,05)$.

Conclusion: There was differences in nutritional status in light physical activity and academic achievement between students from poor and those from non poor families.

KEY WORDS: nutritional status, physical activities, academic achievement, poor families

\section{PENDAHULUAN}

Status gizi dikatakan baik atau optimal apabila tubuh memperoleh cukup zat gizi dan dapat digunakan secara efisien, sehingga memungkinkan pertumbuhan fisik dan otak, kemampuan aktivitas fisik dan kesehatan secara umum pada tingkat setinggi mungkin (1).

Pada umumnya status gizi yang baik memungkinkan seseorang melakukan aktivitas yang tinggi. Aktivitas yang dilakukan dengan teratur selama beberapa minggu menyebabkan penurunan massa tubuh sekitar 1-3 kg, penurunan lemak tubuh, dan bila aktivitas dilakukan berlebihan maka akan terjadi penurunan berat badan (2). Gizi kurang yang berlangsung lama (kronis) dapat mendatangkan kerugian pada anak didik, salah satunya adalah prestasi akademik yang rendah (3).

Status gizi pada remaja akan memiliki dampak negatif pada tingkat kesehatan masyarakat, misalnya penurunan prestasi akademik dan kesehatan jasmani (2). Dengan demikian, status gizi yang baik akan dapat menunjang peningkatan prestasi akademik. Prestasi akademik memiliki hubungan yang erat dengan tingkat kecerdasan dan sangat dipengaruhi oleh jumlah atau banyaknya sel otak seseorang (4).

Aktivitas fisik berkaitan erat dengan kesehatan tubuh secara keseluruhan. Tubuh yang sehat akan mampu melakukan aktivitas secara optimal. Aktivitas yang dilakukan secara rutin dalam porsi yang cukup mempunyai dampak positif terhadap kesehatan tubuh. Beberapa literatur mengemukakan bahwa aktivitas fisik (termasuk olahraga) dan asupan zat gizi mempunyai dampak yang sinergis terhadap kesehatan jasmani. Kesehatan jasmani merupakan manifestasi dari keseimbangan antara aktivitas fisik dan zat-zat gizi. Gambaran keseimbangan ini dapat dilihat dari penampilan fisik atau status gizi berdasarkan antropometri (5).

Sampai tahun 1996, penduduk miskin di Indonesia terus mengalami penurunan, baik jumlah maupun persentasenya. Pada tahun 1980, penduduk miskin berjumlah 42,3 juta jiwa (28,7\%), turun menjadi $15,1 \%$ pada tahun 1990, dan menjadi 11,3\% pada tahun 1996. Namun dengan terjadinya krisis ekonomi pertengahan tahun 1997 sampai tahun 1998, jumlah penduduk miskin meningkat kembali pada tahun 2002 sehingga mencapai

\footnotetext{
Politeknik Kesehatan, Manado

2 Politeknik Kesehatan, Yogyakarta

3 Magister Gizi dan Kesehatan UGM, Yogyakarta
} 
angka 18,2\% (6). Data tahun 2002 menunjukkan jumlah penduduk miskin di Provinsi Sulawesi Utara yaitu 229.310 jiwa, yang tinggal di wilayah perkotaan sebanyak 36.590 jiwa $(15,96 \%)$ dan yang tinggal di wilayah pedesaan sebanyak 192.720 jiwa $(84,0 \%)(7)$.

Kota Bitung merupakan salah satu kota di Provinsi Sulawesi Utara dengan kebijakan pemerintahan yang memberikan bantuan biaya pendidikan kepada semua siswa yang berasal dari keluarga miskin mulai dari SD (sekolah dasar) sampai dengan SMA (sekolah menengah atas), yang bertujuan membantu siswa tersebut untuk meningkatkan prestasi akademik dan tetap melanjutkan sekolah (8).

Penelitian ini secara umum bertujuan untuk mengetahui perbedaan status gizi, aktivitas fisik, dan prestasi akademik siswa SMA gakin (warga miskin) dan non-gakin di Kota Bitung.

\section{BAHAN DAN METODE}

\section{Rancangan penelitian dan sampel}

Penelitian ini merupakan penelitian observasional dengan menggunakan rancangan cross sectional untuk melihat perbedaan status gizi, aktivitas fisik, dan prestasi akademik siswa SMA gakin dan non-gakin di Kota Bitung.

Populasi dalam penelitian ini adalah seluruh siswa SMA, baik negeri maupun swasta yang ada di Kota Bitung, sedangkan sampel adalah bagian dari populasi tersebut. Sampel dipilih secara proportional stratified random sampling dan dihitung berdasarkan rumus (9). Sesuai perhitungan, maka jumlah sampel minimal adalah 157 siswa gakin dan 157 siswa non-gakin. Sampel kemudian dikelompokkan berdasarkan umur, jenis kelamin, dan kelas. Pemilihan sampel SMA diambil secara keseluruhan (terdiri atas dua SMA negeri dan empat SMA swasta). Kriteria inklusi pada sampel penelitian ini yaitu: umur 16-18 tahun, masih memiliki ayah dan ibu, siswa gakin yang menerima bantuan dan siswa non-gakin yang tidak menerima bantuan biaya pendidikan, bertempat tinggal di wilayah Kota Bitung, serta bersedia ikut dalam penelitian.

\section{Cara pengumpulan data}

Data yang dikumpulkan dalam penelitian ini meliputi: data identitas dan karakteristik sampel, status gizi, jenis aktivitas fisik, serta asupan energi dan protein siswa.

Data identitas dan karakteristik sampel meliputi tingkat pendidikan dan pekerjaan orang tua yang diperoleh dengan mengedarkan kuesioner pada sampel.

Pengumpulan data untuk status gizi diperoleh melalui pengukuran IMT (indeks massa tubuh). IMT diperoleh dari perhitungan BB (berat badan dalam $\mathrm{kg}$ ) dibagi TB $^{2}$ (tinggi badan dalam meter). Nilai ambang IMT dikelompokkan berdasarkan kriteria Willet (10). Berat badan diukur dengan menggunakan timbangan injak yang mempunyai kapasitas $150 \mathrm{~kg}$ dengan ketelitian $0,1 \mathrm{~kg}$, sedangkan data tinggi badan diukur dengan microtoise yang mempunyai panjang maksimal $200 \mathrm{~cm}$ dengan ketelitian $0,1 \mathrm{~cm}$.

Pengumpulan data jenis aktivitas fisik diperoleh dengan menggunakan kuesioner aktivitas fisik model IPAQ (international physical activity questionnaire) yang telah dimodifikasi dan dikelompokkan menjadi jenis aktivitas fisik ringan, sedang, dan berat.

Data asupan energi dan protein siswa dikumpulkan dengan menggunakan metode food recall 24 jam. Jumlah hari recall ditentukan berdasarkan perhitungan dengan rumus (10), sebanyak 4 kali jumlah bahan makanan yang dikonsumsi pada periode 24 jam sebelumnya diterjemahkan dalam ukuran rumah tangga (URT). Kemudian dari URT dikonversi ke dalam ukuran berat (gram) untuk dianalisis. Jumlah zat gizi yang dikonsumsi terutama energi dan protein dibandingkan dengan \%AKG.

\section{Analisis data}

Tahap pertama yang dilakukan yaitu entry data dengan menggunakan program komputer, selanjutnya dianalisis secara deskriptif dalam bentuk uraian, tabel, grafik, dan lain-lain. Untuk menguji perbedaan karakteristik subjek dilakukan $t$-test.

Analisis statistik untuk menjawab hipotesis penelitian tentang perbedaan status gizi, aktivitas fisik, dan prestasi akademik menggunakan t-test, chi square, dan kruskal wallis, sedangkan analisis hubungan antara asupan energi dan protein dengan status gizi, aktivitas fisik, dan prestasi akademik menggunakan uji regresi linier, pada tingkat kepercayaan $95 \%$, dengan bantuan program komputer.

\section{HASIL}

\section{Karakteristik sampel}

Sampel dalam penelitian ini berjumlah 157 siswa gakin dan 157 siswa non-gakin, yang terdiri atas 140 siswa laki-laki dan 174 siswa perempuan. Umur sampel yang terbanyak adalah 17 tahun, tersebar di 6 SMA yang ada di Kota Bitung.

Pendidikan ayah dan ibu dari siswa non-gakin yang terbanyak adalah tingkat SMA masing-masing sebesar $54 \%$ dan $38,7 \%$. Pekerjaan ayah dari siswa non-gakin terbanyak adalah pegawai swasta yaitu $47,8 \%$, sementara ibu adalah PNS sebesar $27,4 \%$. Pekerjaan ayah dari siswa gakin yang terbanyak adalah nelayan $49,0 \%$, sementara ibu siswa gakin yang terbanyak berprofesi sebagai IRT (ibu rumah tangga) sebesar $84,7 \%$ dan petani sebesar $52,3 \%$. 
Hasil penelitian menunjukkan jumlah siswa dengan asupan energi $\geq 100 \%$ AKG pada siswa gakin mencapai $58,6 \%$, sementara pada siswa non-gakin mencapai $74,5 \%$. Jumlah siswa non-gakin dengan asupan protein $\geq 100 \%$ AKG sebanyak $76,4 \%$, sementara pada siswa gakin sebanyak $50,3 \%$. Siswa dengan asupan energi $<100 \%$ AKG sebesar $41,4 \%$ pada siswa gakin, jauh lebih tinggi dibanding siswa non-gakin yaitu sebesar $25,5 \%$, sedangkan jumlah siswa dengan asupan protein $<100 \%$ AKG yang gakin mencapai $49,7 \%$ lebih tinggi daripada siswa non-gakin yaitu sebesar $23,6 \%$. Hasil uji statistik membuktikan terdapat perbedaan asupan energi dan protein pada siswa SMA gakin dan non-gakin di Kota Bitung $(p<0,05)$, dengan rata-rata asupan energi pada siswa gakin dan non-gakin masing-masing sebesar 2.236,3 $\mathrm{kkal} /$ hari dan 2.297,9 kkal/hari, serta 55,3 g dan 59,2 g per hari untuk asupan protein.

\section{Perbedaan status gizi siswa gakin dan non-gakin di Kota Bitung}

Pada penelitian ini, rata-rata berat badan siswa nongakin lebih berat $1,8 \mathrm{~kg}$ dibanding siswa gakin, demikian juga dengan tinggi badan siswa non-gakin yang lebih tinggi $3,3 \mathrm{~cm}$ dibanding siswa gakin. Rata-rata status gizi siswa gakin berbeda nyata dengan siswa non-gakin $(p<0,05)$. Siswa gakin yang mempunyai status gizi kurus sebanyak $14,0 \%$, yang mempunyai status gizi normal sebanyak 82,1 , dan yang mempunyai status gizi gemuk sebanyak $3,8 \%$; sedangkan siswa non-gakin yang mempunyai status gizi kurang sebanyak $0,6 \%$, yang mempunyai status gizi normal mencapai $92,3 \%$, serta yang mempunyai status gizi gemuk sebanyak 7,0\% (Gambar 1).

\section{Perbedaan aktivitas fisik siswa gakin dan non-gakin}

Hasil pengukuran aktivitas fisik siswa gakin dan nongakin dapat dilihat pada Tabel 1. Rata-rata aktivitas fisik ringan berbeda secara signifikan antara siswa gakin dan non-gakin $(p<0,05)$, sementara rata-rata aktivitas sedang, berat, dan tidur tidak berbeda secara signifikan antara siswa gakin dan non-gakin $(p>0,05)$.

Nilai mean dari total aktivitas ringan pada siswa gakin sebesar 14,0 jam/hari dan lebih rendah 0,7 jam dibanding pada siswa non-gakin sebesar 14,7 jam/hari. Hal ini menunjukkan bahwa aktivitas ringan lebih lama dilakukan oleh siswa non-gakin. Pada aktivitas sedang tidak terdapat perbedaan yang bermakna $(p>0,05)$, walaupun terdapat perbedaan rata-rata dalam jumlah jam sehari yaitu sebanyak 11,6 jam pada siswa gakin dan 11,8 jam pada siswa non-gakin. Demikian juga dengan rata-rata aktivitas berat tidak terdapat perbedaan nilai median yaitu $1,9 \mathrm{jam}$ pada siswa gakin dan 2,3 jam pada siswa non-gakin $(p>0,05)$.

Jenis-jenis aktivitas ringan yang dilakukan oleh siswa gakin dan non-gakin dapat dilihat pada Tabel 2. Aktivitas les bahasa Inggris antara siswa gakin dan non-gakin berbeda secara signifikan $(p<0,05)$. Hal ini ditunjukkan dengan ratarata jumlah jam/hari sebanyak 1,6 jam pada siswa nongakin dan $0,8 \mathrm{jam}$ pada siswa gakin. Demikian pula dengan aktivitas pekerjaan rumah lebih lama dilakukan oleh siswa gakin yakni sebesar 4,3 jam/hari dibanding dengan siswa

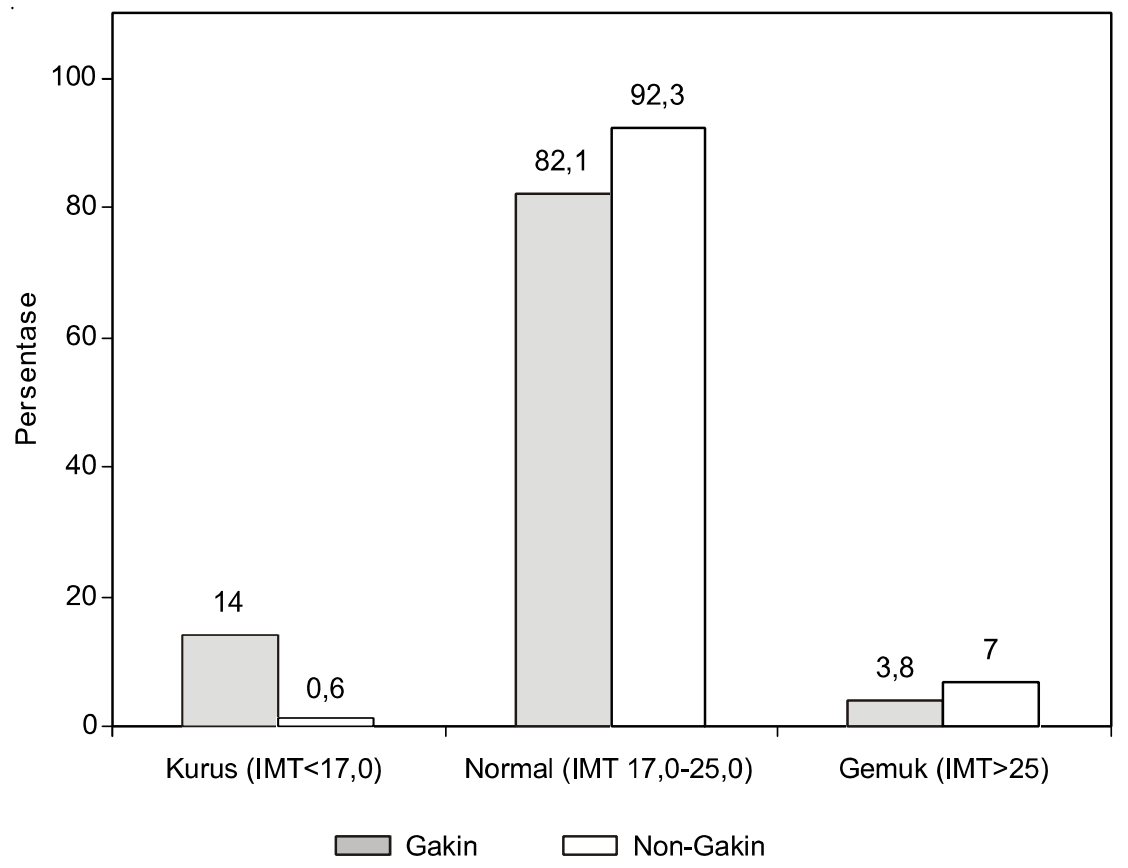

GAMBAR 1. Persentase status gizi berdasarkan IMT siswa gakin dan non-gakin 
TABEL 1. Hasil pengukuran rata-rata durasi aktivitas fisik siswa gakin dan non-gakin di Kota Bitung

\begin{tabular}{cccc}
\hline Variabel & Gakin & Non-gakin & p \\
\hline Mean (IK 95\%) & & & \\
aktivitas fisik ringan (jam/hari) & $14,0(12,6-15,8)$ & $14,7(13,2-16,2)$ & $0,047^{*}$ \\
aktivitas fisik sedang (jam/hari) & $11,6(11,3-11,9)$ & $11,8(11,6-12,1)$ & 0,222 \\
aktivitas tidur (jam/hari) & $8,3(8,1-8,4)$ & $8,4(8,2-8,6)$ & 0,225 \\
Median (Q1;Q3) & $1,9(1,7-2,2)$ & $2,3(1,5-2,4)$ & 0,152 \\
aktivitas fisik berat (jam/minggu ) & & &
\end{tabular}

Keterangan :

* Signifikan $(p<0,05)$

TABEL 2. Jenis-jenis aktivitas ringan dan jumlah jam per hari yang dilalui siswa gakin dan non-gakin di Kota Bitung

\begin{tabular}{|c|c|c|c|}
\hline \multirow[t]{2}{*}{ Aktivitas } & \multicolumn{2}{|c|}{$\begin{array}{c}\text { Mean (IK 95\%) } \\
\text { (jam/hari) }\end{array}$} & \multirow[t]{2}{*}{$\mathbf{p}$} \\
\hline & Gakin & Non-gakin & \\
\hline Duduk santai & $4,5(4,2-4,9)$ & $4,9(4,6-5,2)$ & 0,109 \\
\hline Naik kendaraan & $1,0(0,8-1,3)$ & $1,2(0,9-1,5)$ & 0,274 \\
\hline Les bahasa Inggris & $0,8(0,5-1,2)$ & $1,6(1,3-1,9)$ & $0,014^{*}$ \\
\hline Pekerjaan rumah & $4,3(4,0-4,7)$ & $3,2(2,9-3,5)$ & $0,000^{*}$ \\
\hline Menonton TV & $3,4(3,1-3,7)$ & $3,8(3,5-4,1)$ & 0,373 \\
\hline
\end{tabular}

non-gakin sebesar 3,2 jam/hari dan hasil uji statistik menunjukkan perbedaan yang signifikan $(p<0,05)$. Aktivitas duduk santai, naik kendaraan, dan menonton TV menunjukkan perbedaan yang tidak signifikan $(p<0,05)$.

Jenis-jenis aktivitas sedang yang dilakukan oleh siswa gakin dan non-gakin dapat dilihat pada Tabel 3. Aktivitas bermain pada siswa non-gakin lebih lama daripada siswa gakin, masing-masing sebanyak 1,7 jam dan 0,7 jam, begitu pula dengan aktivitas senam siswa non-gakin memiliki durasi yang lebih lama 1,1 jam dibanding siswa gakin, dan aktivitas kegiatan pramuka siswa non-gakin lebih lama 0,8 jam dibanding siswa gakin. Hasil uji statistik aktivitas bermain, senam, dan kegiatan pramuka antara siswa gakin dan non-gakin menunjukkan hasil yang berbeda secara signifikan $(p<0,05)$. Hasil uji statistik aktivitas sedang yang lain seperti: jalan kaki, duduk di kelas, dan belajar di kelas menunjukkan tidak ada perbedaan antara siswa gakin dan non-gakin $(p>0,05)$.

Rata-rata aktivitas fisik berat (sepak bola, basket, dan voli) pada siswa gakin dan non-gakin tidak berbeda secara signifikan ( $p>0,05)$, namun pada jenis kegiatan olahraga bela diri terlihat adanya perbedaan antara siswa gakin dan non-gakin $(p<0,05)$. Siswa non-gakin melakukan aktivitas bela diri lebih lama dibanding siswa gakin yang ditunjukkan dari median durasi aktivitas per minggu, masing-masing sebesar 2,3 jam dan 1,8 jam (Tabel 4).

\section{Perbedaan prestasi akademik siswa gakin dan non-gakin}

Hasil penelitian ini membuktikan adanya perbedaan prestasi akademik antara siswa gakin dan non-gakin dengan nilai $p=0,015(p<0,05)$. Hal ini terlihat dari nilai

TABEL 3. Jenis-jenis aktivitas sedang dan jumlah jam per hari yang dilalui siswa gakin dan non-gakin di Kota Bitung

\begin{tabular}{lccc}
\hline \multirow{2}{*}{ Aktivitas } & \multicolumn{2}{c}{$\begin{array}{c}\text { Mean (IK 95\%) } \\
\text { (jam/hari) }\end{array}$} & p \\
\cline { 2 - 4 } & Gakin & Non-gakin & \\
\cline { 2 - 4 } & $0,6(0,4-0-8)$ & $0,3(0,1-0,6)$ & 0,133 \\
Jalan kaki & $5,3(5,2-5,5)$ & $5,3(5,0-5,6)$ & 1,000 \\
Duduk di kelas & $5,2(5,0-5,3)$ & $5,2(5,0-5,4)$ & 1,000 \\
Belajar di kelas & $0,7(0,8-1,3)$ & $1,7(1,4-2,0)$ & $0,001^{*}$ \\
Sermain & $0,5(0,9-1,3)$ & $1,6(1,4-1,9)$ & $0,001^{*}$ \\
Pramuka & $0,7(0,6-1,9)$ & $1,5(1,3-2,1)$ & $0,000^{*}$ \\
\hline
\end{tabular}

Keterangan:

* Signifikan $(p<0,05)$ 
TABEL 4. Jenis-jenis aktivitas berat dan durasi per minggu yang dilalui siswa SMA gakin dan non-gakin di Kota Bitung

\begin{tabular}{lcrc}
\hline \multirow{2}{*}{ Aktivitas } & \multicolumn{2}{c}{$\begin{array}{c}\text { Median (Q1;Q3) } \\
\text { (jam/ minggu) }\end{array}$} & p \\
\cline { 2 - 3 } & \multicolumn{1}{c}{ Gakin } & Non-gakin & \\
\hline Sepak bola & $2,1(2,0-4,5)$ & $2,4(2,0-4,6)$ & 0,351 \\
Bela diri & $1,8(1,0-3,0)$ & $2,3(2,0-4,0)$ & $0,037^{*}$ \\
Basket & $1,9(1,1-2,8)$ & $2,2(2,0-4,5)$ & 0,264 \\
Voli & $2,0(1,5-4,2)$ & $2,3(2,0-4,6)$ & 0,169 \\
\hline Keterangan : & & & \\
* Signifikan $(p<0,05)$ & & &
\end{tabular}

rata-rata rapor semester I dan II yang hasilnya menunjukkan prestasi akademik siswa non-gakin lebih tinggi dibanding siswa gakin. Sebanyak 7,6\% siswa non-gakin memiliki prestasi baik, sementara siswa gakin hanya sebanyak $0,6 \%$. Untuk kategori nilai cukup yang terbanyak dimiliki oleh sebagian besar $(77,7 \%)$ siswa non-gakin, sedangkan pada siswa gakin hanya sebesar $45,8 \%$. Sebaliknya, untuk kategori nilai kurang yang terbanyak pada siswa gakin yakni sebesar $53,5 \%$, sedang pada siswa non-gakin sebesar 4,4\% (Gambar 2).

\section{Variabel luar yang berhubungan dengan status gizi, aktivitas fisik, dan prestasi akademik}

Hubungan variabel luar dengan status gizi, aktivitas fisik, dan prestasi akademik dapat dilihat pada Tabel $\mathbf{5}$. Dari tabel tersebut diketahui bahwa hanya \% AKG energi yang secara statistik berhubungan dengan status gizi $(p<0,05)$, sedangkan variabel pendidikan ayah dan ibu, pekerjaan ayah dan ibu, serta \% AKG protein menunjukkan tidak terdapat hubungan yang signifikan $(p>0,05)$.

Selain itu, hanya pekerjaan ayah yang terbukti berhubungan dengan aktivitas fisik ringan $(p<0,05)$, sedangkan variabel luar lainnya (pendidikan ayah, pendidikan ibu, pekerjaan ibu, \%AKG energi, dan \%AKG protein) tidak berhubungan dengan aktivitas ringan $(p>0,05)$. Sementara variabel luar yang berhubungan dengan aktivitas fisik sedang adalah variabel pendidikan ayah dan pekerjaan ayah $(p<0,05)$, namun tidak satu pun dari variabel luar pada penelitian ini yang berhubungan dengan aktivitas berat $(p>0,05)$.

Hasil statistik juga membuktikan bahwa variabel pendidikan ayah, pendidikan ibu, pekerjaan ayah, dan \% AKG protein berhubungan dengan prestasi akademik

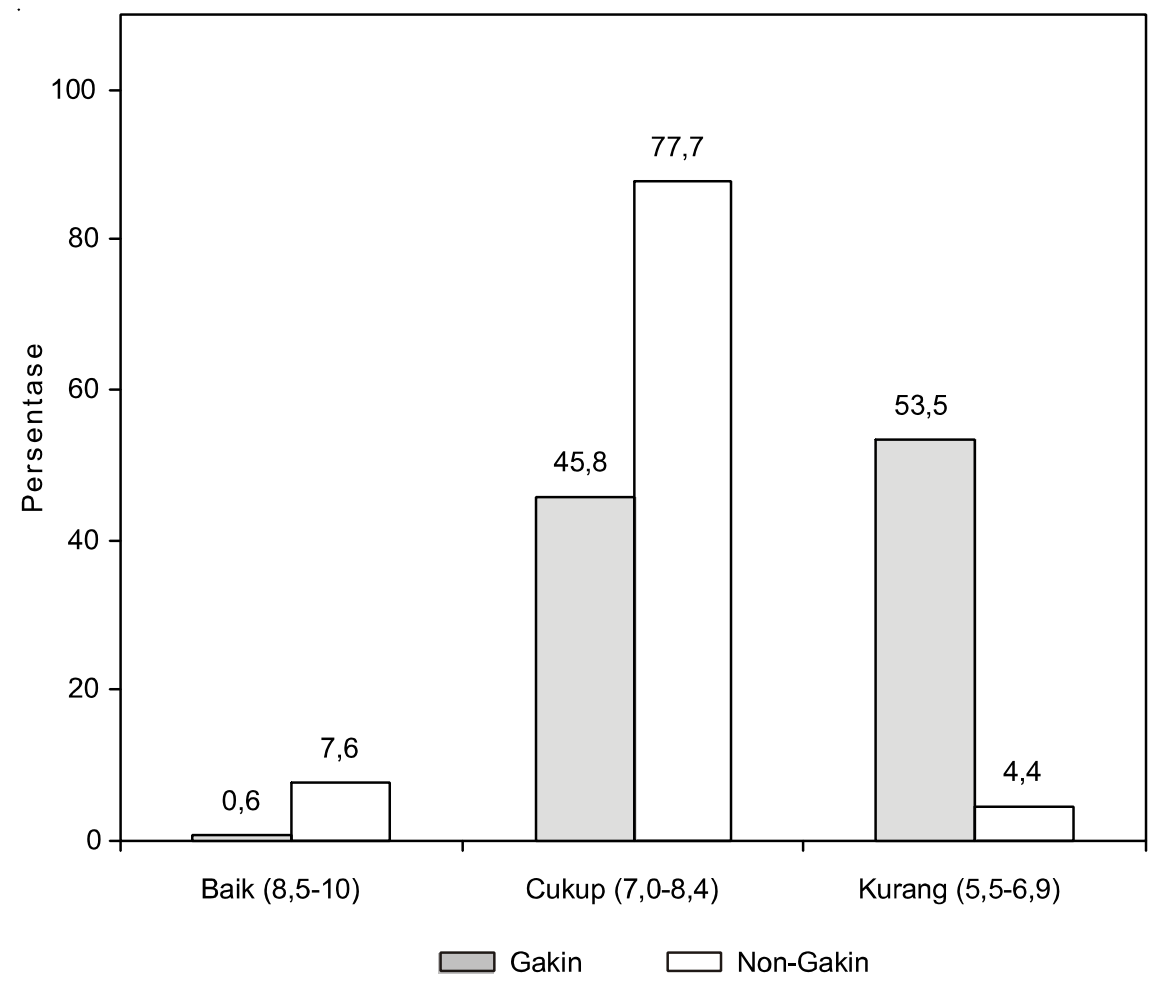

GAMBAR 2. Persentase prestasi akademik siswa gakin dan non-gakin 
TABEL 5. Variabel luar yang berhubungan dengan status gizi, aktivitas fisik, dan prestasi akademik

\begin{tabular}{lccc}
\hline Variabel & $\begin{array}{c}\text { Koefisien } \\
\text { regresi }\end{array}$ & $\begin{array}{c}\text { Standard } \\
\text { error }\end{array}$ & $\mathbf{p}$ \\
\hline Status gizi & & & \\
Konstanta & -5.373 & 2.742 & 0,051 \\
Pendidikan ayah & 0,012 & 0,183 & 0,863 \\
Pendidikan ibu & 0,089 & 0,179 & 0,190 \\
Pekerjaan ayah & 0,077 & 0,102 & 0,221 \\
Pekerjaan ibu & $-0,042$ & 0,123 & 0,402 \\
\% AKG energi & 0,466 & 0,031 & $0,000^{*}$ \\
\% AKG protein & 0,011 & 0,023 & 0,865 \\
Aktivitas fisik ringan & & & \\
Konstanta & 8.171 & 4.775 & 0,088 \\
Pendidikan ayah & 0,011 & 0,319 & 0,892 \\
Pendidikan ibu & 0,071 & 0,311 & 0,342 \\
Pekerjaan ayah & $-0,166$ & 0,178 & $0,016^{*}$ \\
Pekerjaan ibu & 0,023 & 0,214 & 0,679 \\
\% AKG energi & 0,128 & 0,054 & 0,065 \\
\% AKG protein & 0,035 & 0,041 & 0,634 \\
Aktivitas fisik sedang & & & \\
Konstanta & 13,01 & 1.817 & 0,000 \\
Pendidikan ayah & $-0,286$ & 0,850 & $0,000^{*}$ \\
Pendidikan ibu & 0,135 & 0,828 & 0,077 \\
Pekerjaan ayah & $-0,175$ & 0,473 & $0,013^{*}$ \\
Pekerjaan ibu & 0,042 & 0,570 & 0,454 \\
\% AKG energi & 0,034 & 0,145 & 0,633 \\
\% AKG protein & $-0,38$ & 0,108 & 0,610 \\
Aktivitas fisik berat & & & \\
Konstanta & 4.717 & 2.460 & 0,056 \\
Pendidikan ayah & 0,058 & 0,164 & 0,471 \\
Pendidikan ibu & 0,037 & 0,160 & 0,633 \\
Pekerjaan ayah & $-0,138$ & 0,091 & 0,051 \\
Pekerjaan ibu & 0,002 & 0,110 & 0,967 \\
\% AKG energi & $-0,001$ & 0,028 & 0,987 \\
\% AKG protein & $-0,083$ & 0,021 & 0,267 \\
Prestasi akademik & & & \\
Konstanta & 6.746 & 0,488 & 0,000 \\
Pendidikan ayah & 0,183 & 0,033 & $0,006^{*}$ \\
Pendidikan ibu & 0,157 & 0,032 & $0,012^{*}$ \\
Pekerjaan ayah & $-0,298$ & 0,018 & $0,000^{*}$ \\
Pekerjaan ibu & $-0,077$ & 0,022 & 0,099 \\
\% AKG energi & $-0,066$ & 0,006 & 0,258 \\
\% AKG protein & 0,143 & 0,004 & $0,019^{*}$ \\
\hline Ketangan : & & &
\end{tabular}

Keterangan :

* Signifikan $(p<0,05)$

siswa $(p<0,05)$, namun variabel luar lainnya seperti pekerjaan ibu dan \% AKG energi tidak berhubungan dengan prestasi akademik siswa $(p>0,05)$.

\section{BAHASAN}

\section{Perbedaan status gizi siswa gakin dan non-gakin di Kota Bitung}

Pada penelitian ini, rata-rata status gizi siswa gakin berbeda nyata dengan siswa non-gakin $(p<0,05)$. Hasil ini sesuai dengan penelitian Prista et al. (11) yang menggunakan pengukuran status gizi dengan metode IMT dan diketahui remaja yang mengalami status gizi kurang sebanyak $21 \%$ dari keluarga miskin dan sebanyak 0,8\% dari keluarga non-miskin. Pengukuran status gizi dengan IMT direkomendasikan sebagai indikator yang baik untuk menentukan status gizi remaja, sedangkan metode antropometri merupakan cara penentuan status gizi yang paling mudah dan murah (12).

Masa remaja merupakan periode dari pertumbuhan dan proses kematangan manusia. Pada masa ini terjadi perubahan yang sangat unik dan berkelanjutan (13). Perubahan fisik karena pertumbuhan yang terjadi akan mempengaruhi status kesehatan dan gizinya. Ketidakseimbangan antara asupan kebutuhan atau kecukupan akan menimbulkan masalah gizi, baik itu berupa masalah gizi lebih maupun gizi kurang (14). Masalah gizi kurang yang terjadi pada remaja akan berdampak negatif pada tingkat kesehatan masyarakat seperti penurunan prestasi akademik dan kesegaran jasmani (2). Selain itu, kekurangan gizi juga akan menyebabkan kegagalan pertumbuhan fisik dan perkembangan kecerdasan, menurunkan produktivitas dan daya tahan, meningkatkan kesakitan dan kematian. Oleh karena itu, gizi merupakan salah satu penentu kualitas sumber daya manusia (1). Banyak penelitian telah dilakukan menunjukkan kelompok remaja banyak menderita/mengalami masalah gizi. Masalah gizi tersebut antara lain IMT kurang dari batas normal atau kurus. Prevalensi remaja dengan IMT kurus berkisar antara $30-40 \%$.

\section{Perbedaan aktivitas fisik siswa gakin dan non-gakin}

Hasil penelitian ini membuktikan bahwa rata-rata aktivitas fisik ringan berbeda secara signifikan antara siswa gakin dan non-gakin $(p<0,05)$, sementara rata-rata aktivitas sedang, berat, dan tidur tidak berbeda secara signifikan antara siswa gakin dan non-gakin $(p>0,05)$.

Aktivitas ringan seperti les bahasa Inggris dan pekerjaan rumah terbukti secara signifikan berbeda antara siswa gakin dan non-gakin $(p<0,05)$. Durasi melakukan pekerjaan rumah pada siswa gakin lebih lama dibanding siswa non-gakin. Hasil penelitian ini sesuai dengan penelitian di Mosambique yang melaporkan bahwa aktivitas pekerjaan rumah lebih lama dikerjakan oleh siswa dari keluarga miskin dibanding dari keluarga tidak miskin (15). Namun begitu, aktivitas fisik pada remaja yang tidak kurang gizi lebih aktif 30 menit dibandingkan yang kurang gizi (11).

Aktivitas sedang seperti: bermain, senam, dan pramuka serta aktivitas berat seperti bela diri terbukti berbeda secara signifikan antara siswa gakin dan nongakin $(p<0,05)$. Aktivitas fisik mengacu pada semua kegiatan yang dilakukan seseorang dengan melibatkan fisik, baik itu dalam bentuk yang formal dengan aturan yang sudah ditentukan seperti aktivitas sedang olahraga, ataupun yang semata-mata dilakukan tanpa mengikuti 
persyaratan dan aturan main tertentu seperti aktivitas ringan pekerjaan rumah (memasak, mencuci pakaian, menyetrika) (16). Huriyati et al. (17) mengemukakan bahwa remaja perkotaan lebih banyak melakukan aktivitas ringan dibanding dengan aktivitas berat dan waktu yang digunakan mencapai 12,4 jam/hari.

Berat-ringannya aktivitas fisik ditentukan oleh besarkecilnya keterlibatan otot (18). Contoh yang diberikan Treuth et al. (19) yaitu ketika seseorang melakukan aktivitas senam, maka yang paling banyak bergerak adalah kedua tangan, sedangkan ketika bermain sepak bola yang lebih banyak bergerak adalah kedua kaki dalam keseluruhan aktivitas fisiknya. Demikian pula dengan aktivitas fisik nonformal lainnya seperti berjalan kaki yang banyak melibatkan gerakan tubuh lengan dan kaki (20).

Besar-kecilnya keterlibatan otot tersebut membutuhkan energi dan protein yang cukup (18). Menurut Arvidson et al. (21), setiap aktivitas fisik mulai yang hanya berlangsung dalam 30 detik hingga aktivitas olahraga yang menggunakan waktu dalam hitungan jam membutuhkan energi dan protein yang seimbang. Energi inilah yang memungkinkan seseorang melakukan tugasnya dengan baik (22). Bennett et al. (23) melaporkan bahwa berbagai jenis kegiatan olahraga seperti: lari, basket, voli, dan sepak bola bila tidak diimbangi dengan konsumsi energi dan protein yang cukup, maka cadangan kalori dalam tubuh akan dipecah untuk menggantikan energi tersebut. Kejadian ini umumnya dialami oleh remaja dari keluarga yang berpenghasilan rendah.

Aktivitas fisik ringan dengan melakukan pekerjaan di rumah seperti mencuci pakaian, menyeterika, memasak dan lain sebagainya direkomendasikan sebagai alternatif penanganan kegemukan karena memerlukan energi yang setara dengan dengan cabang olahraga lari dan senam (11).

\section{Perbedaan prestasi akademik siswa gakin dan non- gakin}

Hasil penelitian menunjukkan ada perbedaan prestasi akademik antara siswa gakin dan non-gakin $(p<0,05)$. Hal ini terlihat dari nilai rata-rata rapor semester I dan II yang menunjukkan bahwa prestasi akademik siswa non-gakin lebih tinggi dibanding siswa gakin. Prestasi akademik merupakan predisposisi tingkat pengetahuan seseorang. $\mathrm{WHO}$ (24) menyatakan bahwa pengetahuan berhubungan dengan sikap dan praktek, sehingga pengetahuan akan mempengaruhi sikap seseorang untuk bertindak. Demikian pula dengan perilaku kesehatan seseorang atau masyarakat yang akan dipengaruhi oleh dua faktor yaitu faktor perilaku dan faktor di luar perilaku (25). Faktor perilaku tersebut ditentukan oleh tiga faktor lain, yaitu: faktor predisposisi yang berupa pengetahuan, sikap, kepercayaan, keyakinan, nilai-nilai, norma sosial, dan faktor sosiodemografi (umur, pendidikan, status ekonomi, pekerjaan, jenis kelamin).

\section{Variabel luar yang berhubungan dengan status gizi, aktivitas fisik, dan prestasi akademik}

Pada penelitian ini terdapat hubungan signifikan antara \% AKG energi dengan status gizi, pekerjaan ayah dengan aktivitas fisik ringan, pendidikan dan pekerjaan ayah dengan aktivitas fisik sedang $(p<0,05)$, namun tidak satu pun dari variabel luar pada penelitian ini yang berhubungan dengan aktivitas berat $(p>0,05)$. Pendidikan ayah, ibu, pekerjaan ayah, dan $\%$ AKG protein juga terbukti berhubungan dengan prestasi akademik siswa $(p<0,05)$. Soekirman (12) melaporkan bahwa orang tua yang berpenghasilan baik akan mempengaruhi asupan protein dan tingkat pencapaian pendidikan anak yang baik. Keadaan sosial keluarga berhubungan dengan pengembangan kecerdasan anak. Anak dari keluarga tidak miskin memiliki tingkat kecerdasan yang lebih tinggi daripada anak yang berada dari keluarga yang miskin (26), namun bukan berarti anak dari keluarga yang tidak miskin dilahirkan untuk lebih cerdas (27).

Jelliffe (28) mengemukakan salah satu faktor yang menentukan keberhasilan dalam pendidikan adalah keadaan kesehatan dan gizi anak sekolah. Pengembangan kemampuan teknologi memerlukan kekuatan otak yang prima. Gizi pada usia dini yang terus dipertahankan secara optimal sampai usia sekolah akan berpengaruh besar pada perkembangan kekuatan otak. Akses pendidikan yang makin baik dan ditunjang oleh kinerja kesehatan dan gizi yang cukup memungkinkan anak-anak usia sekolah dapat memaksimalkan potensi dirinya untuk menjadi pribadipribadi berkualitas dan cerdas.

Salah satu akibat kekurangan gizi yang sulit untuk dipulihkan adalah penurunan kecerdasan. Santoso dan Ranti (29) membuktikan bahwa pemberian makanan bergizi yang cukup akan menentukan tingkat intelejensi. Anak yang kurang gizi mempunyai intelejensi yang lebih rendah dibanding anak yang tidak kurang gizi. Rendahnya status gizi anak-anak sekolah akan berdampak negatif pada kualitas SDM (sumber daya manusia). Meski belum sepenuhnya konklusif, namun diyakini bahwa kekurangan gizi kronis berhubungan erat dengan pencapaian akademik murid sekolah yang makin rendah. Meskipun demikian, pendidikan tidak luput dari berbagai masalah seperti keterbatasan pemahaman keluarga akan arti penting gizi bagi pendidikan anak dan dapat mempengaruhi prestasi akademik siswa. Selain mempengaruhi tingkat kecerdasan, penelitian lain membuktikan kurang gizi menyebabkan anak-anak lebih banyak terlambat masuk sekolah, sering absen, dan tidak naik kelas (26). 


\section{KESIMPULAN DAN SARAN}

Ada perbedaan status gizi, aktivitas fisik, dan prestasi akademik antara siswa SMA gakin dan non-gakin. Adanya perbedaan ini hendaknya ditindaklanjuti oleh pemerintah daerah dengan tujuan untuk mengatasi masalah kemiskinan yang ada di Kota Bitung.

Selain itu, siswa gakin juga perlu mengkonsumsi energi dan protein lebih banyak untuk mengurangi persentase siswa gakin yang asupannya kurang dari 100\% AKG. Untuk itu, keluarga miskin yang umumnya berprofesi sebagai nelayan sebaiknya tidak menjual secara keseluruhan hasil tangkapan, supaya kebutuhan protein tercukupi. Para perumus kebijakan pasar sebaiknya juga memperhatikan kebutuhan dan daya beli masyarakat miskin dengan mengatur harga batas tertinggi dan terendah sehingga keluarga miskin bisa menjangkau kebutuhannya.

Pada penelitian ini akan lebih baik dilengkapi dengan analisis pola konsumsi, pola aktivitas, dan tes akademik lain untuk mengetahui adanya hambatan motorik, tingkat kecerdasan, pengaruh lingkungan sosial, dan daya dukung fasilitas sekolah pada siswa gakin dan non gakin.

\section{Ucapan Terima Kasih}

Peneliti mengucapkan terima kasih kepada seluruh siswa yang telah berpartisipasi dalam penelitian ini, kepada Kepala Dinas Pendidikan Nasional Kota Bitung, dan para Kepala Sekolah SMA yang bersedia dijadikan lokasi penelitian.

\section{RUJUKAN}

1. Almatsier S. Prinsip Dasar Ilmu Gizi. Jakarta:Gramedia Pustaka Utama;2003.

2. Soetjiningsih. Tumbuh Kembang Remaja dan Permasalahannya. Jakarta:Sagung Seto; 2004.

3. Enoch M. Karena Kurang Gizi Kemampuan Belajar Anak Berkurang. Medika 1989;(3):287-90.

4. Soejono SM, Masrun, Hadi S. Prestasi Belajar Mahasiswa PMDK dan Non-PMDK (Ditinjau dari Segi Intelegensi, Kebiasaan Belajar, Pendidikan Orang Tua, Status Sekolah dan Jenis Kelamin di FKIP Universitas Sebelas Maret Surakarta. Yogyakarta: BPPSUGM; 1989.

5. Widodo US dan Syafrudin. Kaitan Tingkat Kegiatan Fisik Remaja dan Kaitannya Dengan Status Gizi. Bogor: Puslitbang Gizi; 1989.

6. Depkes RI. Penelitian Gizi dan Makanan. Bogor: Pusat Penelitian dan Pengembangan Gizi; 2000.

7. BPS Provinsi Sulawesi Utara. Survei Sosial Ekonomi Nasional Sulawesi Utara 2003. Sulawesi Utara: BPS Provinsi Sulut; 2003.
8. Pemerintah Kota Bitung. Pembebasan Dana Pendidikan. Surat Keputusan Walikota Bitung. Bitung; Tanggal 21 Oktober 2004. Nomor: 420/PDK/642.

9. Lemeshow S, Hosmer D, Klar J. 1990. Adequacy of Sample Size in Health Studies. (Terjemahan) Pramono D. Yogyakarta: UGM Press; 1997. h. 49-52.

10. Willet W. Nutritional Epidemiology. New York:Oxford University Press; 1990.

11. Prista A, Maia JAR, Damasceno A, Beunen G. Anthropometric Indicator of Nutritional Status: Implication for Fitness, Activity, and Health in School Age Children and Adolescents from Maputo, Mosambique. Am J Clin Nutr 2003;77:952-9.

12. Soekirman. IImu Gizi dan Aplikasinya. Jakarta: Departemen Pendidikan Nasional; 2000.

13. Azwar A, editor. Aspek Kesehatan dan Gizi dalam Ketahanan Pangan. Prosiding WNPG VIII; 17-19 Mei 2004; Jakarta.

14. Hadi H. Gizi Lebih sebagai Tantangan Baru dan Implikasinya terhadap Kebijakan Pembangunan Kesehatan Nasiona. Jurnal Gizi Klinik Indonesia 2004;1(2):51-8.

15. Benefice E, Ndiaye G. Relationships between Antrhopometry, Cardiorespiratoty Fitness Indices and Physical Activity Levels in Different Age and Sex Groups in Rural Senegal (West Africa). Ann Hum Biol 2005;32:366-82.

16. Goran MI. Measurement Issues Related to Studies of Chilhood Obesity: Assessment of Body Composition, Body Fat Distribution, Physical Activity, and Food Intake. Pediatr 1998;101:505-18.

17. Huriyati E, Hadi H, Julia M. Aktivitas Fisik pada Remaja SLTP Kota Yogyakarta dan Kabupaten Bantul serta Hubungannya dengan Kejadian Obesitas. Jurnal Gizi Klinik Indonesia 2004;1(2):59-66.

18. Nurachmah E. Nutrisi dalam Keperawatan. Jakarta: Sagung Seto; 2001.

19. Treuth SM, Hou N, Young DR, Maynard LM. Accelerometry Measured Activity or Sedentary Time and Overweigth in Rular Boy and Girls. Obes Res 2005;13:1606-14.

20. Faith MS, Leone MA, Ayers TS, Heo M, Pietrobelli A. Weight Criticism during Physical Activity, Coping Skills, and Reported Physical Activity in Children. Pediatr 2002;110:e23-e23.

21. Arvidson D, Slinde F, Hulthen L. Physical Activity Questionnaire for Adolescents Validate Against Doubly Labeled Water. Eur J Clin Nutr 2004;59:376-83.

22. Ekelund U, Aman J, Yngve A, Renman C, Westerterp K, Sjostrom M. Physical Activity but Not Energy Expenditure is Reduced in Obese Adolescents. Am J Clin Nutr 2002;76:935-41. 
23. Bennett GG, Wolyn KY, Viswanath K, Askew S, Puleo E, Emmons KM. Television Viewing and Pedometer-Determined Physical Activity among Multiethic Residents of Low-Income Housing. Am J Public Health 2006;96(9):1681-85.

24. WHO. Pendidikan Kesehatan; Pedoman Kesehatan Dasar. Bali: Universitas Udayana; 1988.

25. Suyono S. Hubungan Timbal Balik antara Kegemukan dan Berbagai Penyakit. Dalam: Suyono S. Kegemukan Masalah dan Penanggulangannya. Jakarta:FKUl;1986.
26. Hawadi RA. A-Z Program Percepatan Belajar dan Anak Berbakat Intelektual. Jakarta:Gramedia Widiasarana Indonesia;2004.

27. Latinulu S, Kartika V. Faktor-Faktor yang Mempengaruhi Kemampuan Motorik Anak Usia 1218 Bulan di Keluarga Miskin dan Tidak Miskin. PGM 2002;25(2):38-48.

28. Jelliffe DB. Kesehatan Anak di Daerah Tropis. Jakarta: Bumi Aksara;1994.

29. Santoso S, Ranti AL. Kesehatan dan Gizi. Jakarta; Rineka Cipta:1999. 